\title{
Plants with Wound Healing Activity: A Review of Recent Clinical Trials
}

\author{
Review Article
}

\section{Subhajit Hazra ${ }^{*}$, Ripudaman Singh ${ }^{2}$}

1. Research Scholar, 2. Associate Professor

University Institute of Pharmaceutical Sciences, Chandigarh University, Chandigarh, Gharuan, Mohali.

\begin{abstract}
A wound is the most common type of injury to a living system. Currently, there is a wide range of pharmacotherapies available therapies for treating wounds in clinical practice. However, there are conditions (pregnancy) or situations (the patient's financial condition) that might limit the use of such treatments. Therefore, in such a case, ethnic or traditional medicines can play a significant role. Thus, the current review aimed to highlight the true potential of these alternative therapies based on real-world evidence from clinical trials.
\end{abstract}

Key Words: Clinical trial, Medicinal plants, Ethnomedicine, Alternative medicine, Wound Healing mechanism.

\section{Introduction}

A wound is a consequence of disorganization in the integrity of the skin. Consequently, wound healing is the process of repairing this discontinuation.(1) Furthermore, depending on its nature, a wound can be classified as acute or chronic.(2) An acute wound follows the physiological healing cascade of coagulation, inflammation, proliferation, and remodeling. In contrast, a chronic wound is linked to an underlying pathology responsible for an impaired healing process.(3) Besides, dysregulation in any phases of wound healing can lead to various problems, including ulcers.(4) While pharmacotherapeutic strategies form the gold standard for wound healing in current clinical practice, ethnic and traditional plants can pitch in here too.

\section{The Wound healing cascade}

Physiological wound healing is an active series of actions that involve the coordination of RBCs, proteins, proteases, growth factors, and extracellular matrix components. The wound healing cascade (5) is divided into four phases: (1) bleeding and hemostasis, (2) inflammation, (3) proliferation, and (4) remodeling. [Figure 1]

\section{Phase 1: Bleeding and Hemostasis/Coagulation}

In this phase, a clot is formed to stop bleeding. This is an important phase as it helps prevent fluid loss from the body and prevents entry of pathogens, thus intending hemostasis. Furthermore, the clot serves as a

\section{* Corresponding Author:}

Ripudaman Singh

Associate Professor,

University Institute of Pharmaceutical Sciences,

Chandigarh University, Chandigarh

Gharuan, Mohali: -140413, India.

Email Id: ripudaman.e9844@cumail.in pool of bioactive factors and provides an extracellular matrix that supports the infiltration of immune cells. Vasoconstriction and platelet aggregation are the two most important aims of this phase.(4)
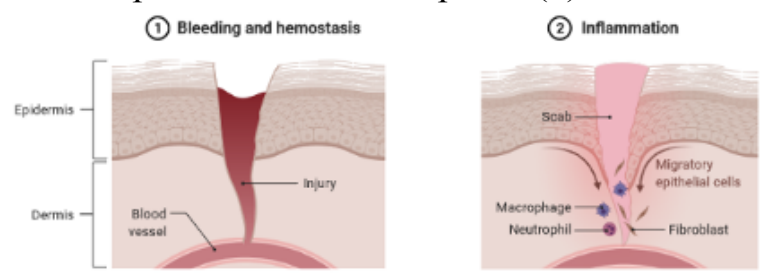

(3) Proliferation

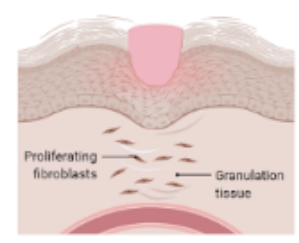

(4) Remodeling

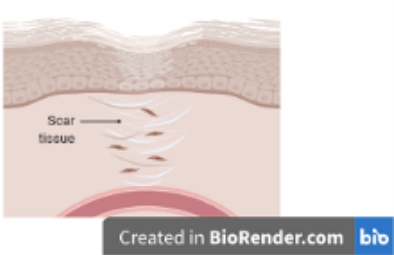

Figure 1: The wound healing cascade in humans

\section{Phase 2: Inflammation}

This phase starts with free radicals and reactive molecular species signalling out to recruit immune cells, increase blood vessel's permeability, and cause the release of antimicrobial species. Next, the infiltrating immune cells secrete damage-associated molecular patterns (DAMPs) as a signal to activate keratinocytes and fibroblasts. Unlike the bleeding and hemostasis phase, the inflammatory phase is mainly concerned with the lysis of microbial cells and their subsequent removal.(4)

\section{Phase 3: Proliferation}

This stage is also known as migration/ granulation/re-epithelialization. The main events occurring in this phase of wound healing include reepithelialization, fibroblast proliferation, collagen synthesis, the formation of granulation tissues, resolution of inflammation, and angiogenesis.(4) 


\section{Phase 4: Remodeling}

This is the last phase of the wound healing process and is also known as the maturation phase. This phase results in the remodeling of collagen or extracellular matrix and apoptosis of fibroblasts.(4) Interestingly, a wound is expected to reach its maximum strength by the end of a year, with a tensile strength that would be seventy percent compared to normal skin.(6)

\section{Aim of the Review}

The current review aimed to highlight the true potential of herbal/ayurvedic therapies available for wound healing based on real-world evidence from clinical trials.

\section{Objective of Review}

To understand and provide an elaborate discussion on the clinical trials, which in turn would help support the use of these plants in the clinics to heal the wounded.

\section{Materials and Methods \\ Search strategy}

To carry out the review, we searched articles from various databases, including PubMed, Scopus, and Web of Science. In addition, all papers that were published in the last five years (2015-21) and discussed about clinical trials pertaining to some wound healing effect were screened. For the retrieval of data from the above databases, a boolean search strategy was used. Furthermore, the keywords used included: medicinal plant and clinical trial and wound healing; wound healing plant and clinical trial; ayurvedic plant and wound healing and clinical trial; medicinal plant and wound healing; wound healing and clinical trial.

\section{Study selection criteria Inclusion criteria}

Publications describing the use of medicinal or ayurvedic plants in clinical trials for wound healing were included in the review. Besides, studies published within the predefined period of 2015-2021 were considered for evaluation.

\section{Exclusion criteria}

Publications were excluded from consideration for this review if they were among the following, such as editor's comments, letters, interviews, guidelines, and manuscripts that did not meet the inclusion criteria.

\section{Clinical trials of traditional used Medicinal plants Aloe vera and Glycyrrhiza glabra}

Aloe vera is probably the most widely known plant used for ages in wound healing. Phytochemical extract of the plant has been seen to contain bioactive compounds such as anthraquinones, glycosides, saponins, and oleic acid.(4) While studies from preclinical studies $(7,8)$ have shown the plant to have an excellent healing activity, its translation to the clinic would only depend on clinical trial results. Indeed, treatment with Aloe vera has been shown to benefit patients suffering from pressure ulcers and recurrent aphthous stomatitis. Similar results have been demonstrated by G.glabra, as summarized in Table 1 .

Table 1: Clinical trial with Aloe vera and G.glabra \begin{tabular}{l|l|l|l} 
Author & Study type Study arms & Study
\end{tabular} (Year) (n)

Hekmatpou D Randomized, Aloe vera Aloe vera et al.(9) triple-blind $\quad(n=39)$ group had (2018) trial $(\mathrm{n}=77)$ Routine care significantly $(n=38) \quad$ lower incidences $(\mathrm{p}$ $=0.047)$ of

pressure ulcer than the control group

Shi Y et al. A randomized Aloe vera gel Aloe vera (10) trial $(\mathrm{n}=13)$ group showed (2020) $\quad(n=34) \quad$ Chitosan gel a greater $(\mathrm{n}=11) \quad$ number of Negative patients control achieving $(\mathrm{n}=10) \quad$ potentially better benefits than the chitosan group

\begin{tabular}{c|c|c|c|}
$\begin{array}{c}\text { Akbari N et } \\
\text { al.(11) } \\
(2020)\end{array}$ & $\begin{array}{c}\text { Double-blind, } \\
\text { randomized } \\
\text { trial } \\
(\mathrm{n}=70)\end{array}$ & $\begin{array}{c}\text { Diphenhydra } \\
\text { mine- } \\
\text { containing } \\
\text { G.glabra } \\
\text { (DSG) }\end{array}$ & $\begin{array}{c}\text { Wounds of } \\
\text { patients on } \\
\text { the DSG } \\
\text { group healed } \\
\text { significantly } \\
\text { faster }(\mathrm{p}=\end{array}$ \\
& & $\begin{array}{c}\text { (n=35) } \\
\text { 0.0001) than } \\
\text { those on the } \\
\text { Diphenhydra } \\
\text { Dine solution }\end{array}$ & DS group \\
& &
\end{tabular}

$(n=35)$

Although the participant number seems to be too small to reach a conclusive decision, however, it could be generally agreed upon that the use of Aloe vera and G.glabra would be an excellent substitute to use (alone or in conjugation) with currently practiced clinical therapies.

\section{Calendula officinalis and Hibiscus rosa-sinensis}

Calendula officinalis, or pot marigold, is a plant with a wide therapeutic presence in treating various skin conditions.(4) This is because preliminary studies have ascertained its role as an anti-inflammatory, antioxidant, and antibacterial agent.(12) However, for establishing its role in the real-world scenario, we need to review results from a clinical trial. To find an answer to this impending question, Buzzi $\mathrm{M}$ and associates conducted a clinical trial to evaluate the efficacy of C.officinalis in treating non-healing venous leg ulcers (VLUs).

Results of trial (13) $(n=57)$ showed that patients achieving complete epithelialization were more in the treatment group $(72 \%)$ than in the control (32\%). Moreover, those in the treatment group (7.4\%) treated had a 4-fold increase in percentage healing velocity/ week than the control $(1.7 \%)$. Therefore, it could be assumed that C.officinalis was indeed beneficial in the treatment of VLUs.(13) Similar beneficial results have 
also been shown by a $4 \%$ leaf extract of Hibiscus rosasinensis ointment. Here, the study was a 12 -week quasiexperimental trial in patients $(\mathrm{n}=12)$ with VLUs. Much to the anticipations derived from preclinical trials,(14) H.rosa-sinensis ointment (applied using compression stockings) helped 10 patients $(83.3 \%)$ to achieve complete remission from ulcers in less than 12 weeks. (15)

\section{Centella asiatica}

Centella asiatica has been tested to have improved healing of chronic ulcers and acute radiation dermatitis in rats. Additionally, it has also shown to enhance collagen deposition and remodeling in guinea pigs and rats.(4) Therefore, to further these therapeutic properties of C.asiatica, both Damkerngsuntorn et al. and Saeidinia A et al. conducted randomized clinical trials with 60 participants each. [Table 2]

\begin{tabular}{|c|c|c|c|}
\hline \multicolumn{4}{|c|}{ Table 2: Clinical trial with $C$.asiatica } \\
\hline $\begin{array}{l}\text { Author } \\
\text { (Year) }\end{array}$ & $\begin{array}{l}\text { Study type } \\
\text { (n) }\end{array}$ & Study arms & $\begin{array}{c}\text { Study } \\
\text { outcomes }\end{array}$ \\
\hline $\begin{array}{c}\text { Damkerngsun } \\
\text { torn W et al. } \\
(16) \\
(2020)\end{array}$ & $\begin{array}{l}\text { Prospective, } \\
\text { randomized, } \\
\text { split-face, } \\
\text { double-blind, } \\
\text { single-center } \\
(\mathrm{n}=60)\end{array}$ & $\begin{array}{c}\text { C.asiatica gel } \\
(0.05 \% \mathrm{w} / \mathrm{w}) \\
(\mathrm{n}=30) \\
\text { Placebo } \\
(\mathrm{n}=30)\end{array}$ & $\begin{array}{l}\text { Patients } \\
\text { treated with } \\
\text { C.asiatica } \\
\text { showed } \\
\text { significantly } \\
\text { less } \\
(\mathrm{p}=0.046) \\
\text { erythema } \\
\text { index as } \\
\text { compared to } \\
\text { the control } \\
\text { group }\end{array}$ \\
\hline $\begin{array}{c}\text { Saeidinia A et } \\
\text { al.(17) } \\
(2017)\end{array}$ & $\begin{array}{c}\text { Randomized } \\
\text { trial } \\
(\mathrm{n}=60)\end{array}$ & $\begin{array}{c}\text { Formulation } \\
\text { containing } \\
\text { C.asiatica } \\
(\mathrm{n}=30) \\
\text { Silver } \\
\text { sulfadiazine } \\
(\mathrm{n}=30)\end{array}$ & $\begin{array}{l}\text { The } \\
\text { formulation } \\
\text { containing } \\
\text { C.asiatica } \\
\text { showed } \\
\text { significant } \\
\text { (p<0.05) re- } \\
\text { epithelializati } \\
\text { on and } \\
\text { complete } \\
\text { healing as } \\
\text { compared to } \\
\text { the silver } \\
\text { sulfadiazine } \\
\text { group }\end{array}$ \\
\hline
\end{tabular}

Therefore trial results confirmed that C.asiatica could be a viable alternative when treating partialthickness caused by burn wounds or in cases of wounds incurred after laser treatment.

\section{Arnebia euchroma, Olive oil, and Alkanna tinctoria}

Preliminary studies with animal models have stated that A. euchroma extracts effectively healed second-degree burn wounds. Similar results have been conferred by a clinical trial conducted by Nasiri $E$ et al. on patients $(\mathrm{n}=90)$ with second-degree burn wounds. In the trial, following the administration of patients with either treatment or control, the healing time was significantly shorter in the case of A.euchroma ointment (13.9 days) compared to silver sulfadiazine cream (17.5 days). Hence, it was understood that A.euchroma could be used as a future treatment therapy for second-degree burn wounds.(18)

Likewise, a trial by Gümüş $\mathrm{K}$ et al. has evidenced the role of olive oil and A.tinctoria extract in patients suffering from burn injuries. The trial included 64 patients $(n=31$ in the experimental group and 33 in control). The trial results showed that the intervention group experienced a significant decrease $(\mathrm{p}<0.05)$ in the length of stay and pain scores (during dressing) as compared to the control.(19)

\section{Portulaca oleracea}

As per the World Health Organization recommendations, infants between 4-6 years of age should be exclusively breastfed.(20) Globally, over $98 \%$ of women can breastfeed their infants (21); however, only $35 \%$ of newborns are breastfed between the 1 st and 5th month.(22) This is so because most women around the world suffer from nipple fissures. More so, at this time around, treating a mother with pharmacotherapy is a challenging task. Therefore, most cases of fissures remain unattended. Recent studies with herbal drugs have pointed out the efficacy of P.oleracea in the treatment of nipple fissure. One such study was a trial conducted by Niazi A et al. The study included 80 participants and aimed to compare the effects of an ointment of P.oleracea to that of control (lanolin). As expected, treatment with P.oleracea showed significant results $(p=0.001)$ in terms of a decreased mean score of breast fissures. So, it can be perceived that ointment formulation containing P.oleracea could be used to treat nipple fissures.(23)

\section{Flaxseed oil and Vasconcellea cundinamarcensis}

A foot ulcer is the most prevalent cause of morbidity in those with diabetes. The use of omega-3 fatty acid in diabetes has been shown to aid in wound healing of these ulcers. Also, it has been seen to lower blood glucose. Such an effect has been confirmed by a trial of 60 subjects with grade III diabetic foot ulcers in clinics. After completion of the 12-week study, omega-3 fatty acids supplementation with flaxseed oil resulted in a significant decrease in length of ulcer $(p=0.03)$, its width $(\mathrm{p}=0.02)$, and depth $(\mathrm{p}=0.01)$ when compared with placebo.(24)

V.cundinamarcensis, though not through omega-3 fatty acid, has shown similar results. More so, the proteolytic fraction of V.cundinamarcensis was witnessed to be 2.95-times more efficacious in meeting the primary endpoint ( $100 \%$ ulcer healing) of the trial. (25)

\section{Silybum marianum}

Cancer is among the leading causes of death globally. In this, breast cancer makes up to $14 \%$ of the fatality. Currently, the most accepted treatment modalities of breast cancer include radio- and chemotherapy. One of the common problems that women face while undergoing radiotherapy is radiation-induced dermatitis. S.marianum has earlier shown to possess antioxidant and anti-inflammatory activities; however, its role in a clinical setting was recently assessed by 
Karbasforooshan $\mathrm{H}$ et al. In the trial, the severity of radiodermatitis was judged every week (for five weeks) by the Radiation Therapy Oncology Group (RTOG) and National Cancer Institute Common Terminology for Adverse Events (NCI-CTCAE) grading scale. Those treated with S.marianum had significantly lower (pvalue $<0.05)$ median scores for NCI-CTCAE and RTOG as compared to control. So, it was assumed that prophylactic use of S.marianum could assist cancer survivors in the management of radiodermatitis.(26)

\section{Achillea millefolium, Hypericum perforatum, Commiphora myrrha, and Pistacia lentiscus}

An episiotomy is a surgical technique intended to reduce the incidences of severe perineal trauma during childbirth. Nevertheless, prolonged wound healing and other compilations continue to limit the use of this technique. At such a juncture, the use of herbal drugs can be of benefit, as indicated by a clinical trial conducted by Hajhashemi M et al., Faraji A et al., and Moudi Z et al. [Table 3]

Table 3: Clinical trial with

A.millefolium, H.perforatum, C.myrrha, and P.lentiscus

\begin{tabular}{l|l|l|l} 
Author & Study type & Study arms & Study
\end{tabular}

$\begin{array}{lll}\text { (Year) (n) } & \text { outcomes }\end{array}$

Hajhashemi Double blind H.perforatum Patients in the

$\mathrm{M}$ et al.(27) trial $(\mathrm{n}=140)$ ointment H.perforatum

(2017)

$$
\begin{aligned}
& \text { A.millefolium A.millefolium } \\
& (\mathrm{n}=35) \quad \text { ointments had } \\
& \text { Non- significantly } \\
& \text { intervention } \quad(\mathrm{P}<0.05) \\
& (n=35) \quad \text { lesser pain }
\end{aligned}
$$

\begin{tabular}{|c|c|c|c|}
\hline $\begin{array}{c}\text { Faraji A et al. } \\
(28) \\
(2021)\end{array}$ & $\begin{array}{c}\text { Randomized } \\
\text { controlled } \\
\text { trial }(n=90)\end{array}$ & $\begin{array}{c}\text { C.myrrh } \\
(\mathrm{n}=30) \\
\\
\text { B.carteri } \\
(\mathrm{n}=30) \\
\text { Placebo } \\
(\mathrm{n}=30)\end{array}$ & $\begin{array}{l}\text { Patients in the } \\
\text { myrrh group } \\
\text { experienced } \\
\text { significant } \\
\text { improvements } \\
\text { in } 2 \mathrm{nd}(\mathrm{p}= \\
0.003 \text { ) and } \\
7 \text { th ( } \mathrm{p}= \\
0.043 \text { ) day } \\
\text { after delivery } \\
\text { in episiotomy } \\
\text { wound } \\
\text { healing than } \\
\text { those in the } \\
\text { B.carteri } \\
\text { oroun }\end{array}$ \\
\hline $\begin{array}{l}\text { Moudi Z et al. } \\
\qquad(29) \\
(2017)\end{array}$ & $\begin{array}{c}\text { Randomized } \\
\text { controlled } \\
\text { trial }(n=121)\end{array}$ & $\begin{array}{l}\text { P.lentiscus } \\
\qquad \begin{array}{l}(\mathrm{n}=60) \\
\text { Control } \\
(\mathrm{n}=61)\end{array}\end{array}$ & $\begin{array}{l}\text { No significant } \\
\text { difference in } \\
\text { episiotomy } \\
\text { healing rates } \\
\text { between } \\
\text { patients in } \\
\text { either of the } \\
\text { two group }\end{array}$ \\
\hline
\end{tabular}

\section{Allium sativum}

A.sativum or garlic has been used for ages as a spice in the culinary industry. However, its role in topical wound healing has only been proposed recently. Therefore to further this role in the case of surgical wounds, Alhashim $\mathrm{M}$ et al. conducted an unblinded, paired comparison trial to compare the surgical wound healing effects of topical garlic ( $30 \%$ ointment) to that of vaseline in patients undergoing surgical removal of skin lesions. The trial results showed that wounds treated with A.sativum had significantly $(p=0.02)$ less when compared to vaseline.(30)

\section{Conclusion}

In all, 17 medical plants interest have been reviewed here based on availability of clinical trial reports since 2015. No plant species were repeated in any of the trials reported. Most of the plant species $(16 / 17)$ stated here had better therapeutic efficacy than its control. Only one trial with Pistacia lentiscus reported having no significant difference in efficacy compared to its control. Moreover, most of the trials had limitations of a small sample size. So large-scale trials are required to fully affirm the role of these medicinal plants in the clinic. Therefore, it could be concluded that there is an urgent need to conduct clinical trials for the huge collection of medicinal plants present in India. Only then can we streamline ayurvedic medicine or ayurvedic system of therapy as one of the primary treatment interventions in India and abroad.

\section{Acknowledgement \\ None}

\section{Conflict of interest}

The authors declare that there is no conflict of interest.

\section{References}

1. Visha M G, Karunagaran M. A review on wound healing. Int J Clinicopathol Correl December,2019;3(2):50-9

2. Jenkins DA, Mohamed S, Taylor JK, Peek N, van der Veer SN. Potential prognostic factors for delayed healing of common, non-traumatic skin ulcers: A scoping review. Int Wound J. February,2019;16(3):800-812

3. Clark RAF, Musillo M, Stransky T. Principles of Tissue Engineering. $5^{\text {th }}$ ed. Elsevier Inc; 2020.1309-1329

4. Shedoeva A, Leavesley D, Upton Z, Fan C. Wound Healing and the Use of Medicinal Plants. Evid Based Complement Alternat Med. September,2019;2019:1-30

5. Maxson S, Lopez EA, Yoo D, DanilkovitchMiagkova A, Leroux MA. Concise review: role of mesenchymal stem cells in wound repair. Stem Cells Transl Med. February,2012;1(2):142-149

6. Sinno H, Prakash S. Complements and the wound healing cascade: an updated review. Plast Surg Int. July,2013;2013:1-7 
7. Teplicki E, Ma Q, Castillo DE, et al. The Effects of Aloe vera on Wound Healing in Cell Proliferation, Migration, and Viability. Wounds. September,2018;30(9):263-268

8. Kayode OA. Effects of aloe vera gel application on epidermal wound healing in the domestic rabbit. International Journal of Research in Medical Sciences. January,2017;5(1):101-105

9. Hekmatpou D, Mehrabi F, Rahzani K, Aminiyan A. The effect of Aloe Vera gel on prevention of pressure ulcers in patients hospitalized in the orthopedic wards: a randomized triple-blind clinical trial. BMC Complement Altern Med. September,2018;18(1):1-11

10. Shi Y, Wei K, Lu J, Wei J, Hu X, Chen T. A Clinic Trial Evaluating the Effects of Aloe Vera Fermentation Gel on Recurrent Aphthous Stomatitis. Can J Infect Dis Med Microbiol. December,2020;2020:1-9

11. Akbari N, Asadimehr N, Kiani Z. The effects of licorice containing diphenhydramine solution on recurrent aphthous stomatitis: A double-blind, randomized clinical trial. Complement Ther Med. May,2020;50:1-5

12. Chandran PK, Kuttan R. Effect of Calendula officinalis Flower Extract on Acute Phase Proteins, Antioxidant Defense Mechanism and Granuloma Formation During Thermal Burns. J Clin Biochem Nutr. September,2008;43(2):58-64

13. Buzzi M, de Freitas F, de Barros Winter M. Therapeutic effectiveness of a Calendula officinalis extract in venous leg ulcer healing. J Wound Care. December,2016;25(12):732-739

14. Firdous SM, Sautya D. Medicinal plants with wound healing potential. Bangladesh J Pharmacol. December,2018;13(1):41-52

15. Maralit Bruan MJ, Tianco EA. Efficacy and Safety of $4 \%$ Hibiscus rosa-sinensis Leaf Extract Ointment as an Adjunct Treatment to Compression Stockings on the Closure of Venous Leg Ulcers: A Pilot Study. Wounds. September,2019;31(9):236-241

16. Damkerngsuntorn W, Rerknimitr P, Panchaprateep $\mathrm{R}$, et al. The Effects of a Standardized Extract of Centella asiatica on Postlaser Resurfacing Wound Healing on the Face: A Split-Face, Double-Blind, Randomized, Placebo-Controlled Trial. J Altern Complement Med. June,2020;26(6):529-536

17. Saeidinia A, Keihanian F, Lashkari AP, et al. Partial-thickness burn wounds healing by topical treatment: A randomized controlled comparison between silver sulfadiazine and centiderm. Medicine (Baltimore). March,2017;96(9):1-9

18. Nasiri E, Hosseinimehr SJ, Zaghi Hosseinzadeh A, Azadbakht M, Akbari J, Azadbakht M. The effects of Arnebia euchroma ointment on second-degree burn wounds: a randomized clinical trial. J Ethnopharmacol. August,2016;189:107-116

19. Gümüş K, Özlü ZK. The effect of a beeswax, olive oil and Alkanna tinctoria (L.) Tausch mixture on burn injuries: An experimental study with a control group. Complement Ther Med. October,2017;34:66-73

20. Gupta PM, Perrine CG, Chen J, Elam-Evans LD, Flores-Ayala R. Monitoring the World Health Organization global target 2025 for exclusive breastfeeding: experience From the United States. J Hum Lact. August,2017;33(3):578-581

21. Mohammadzadeh A, Farhat A, Esmaeily H. The effect of breast milk and lanolin on sore nipples. Saudi Med J. August,2005;26(8):1231-1234

22. Agunbiade OM, Ogunleye OV. Constraints to exclusive breastfeeding practice among breastfeeding mothers in Southwest Nigeria: implications for scaling up. Int Breastfeed $\mathrm{J}$. April,2012;7(1):1-10

23. Niazi A, Yousefzadeh S, Rakhshandeh H, Esmaily $\mathrm{H}$, Askari VR. Promising effects of purslane cream on the breast fissure in lactating women: A clinical trial. Complement Ther Med. April,2019;43:300-305

24. Soleimani Z, Hashemdokht F, Bahmani F, Taghizadeh M, Memarzadeh MR, Asemi Z. Clinical and metabolic response to flaxseed oil omega-3 fatty acids supplementation in patients with diabetic foot ulcer: A randomized, double-blind, placebocontrolled trial. J Diabetes Complications. September,2017;31(9):1394-1400

25. Tonaco LAB, Gomes FL, Velasquez-Melendez G, Lopes MTP, Salas CE. The Proteolytic Fraction from Latex of Vasconcellea cundinamarcensis (P1G10) Enhances Wound Healing of Diabetic Foot Ulcers: A Double-Blind Randomized Pilot Study. Adv Ther. April,2018;35(4):494-502

26. Karbasforooshan H, Hosseini S, Elyasi S, Fani Pakdel A, Karimi G. Topical silymarin administration for prevention of acute radiodermatitis in breast cancer patients: A randomized, double-blind, placebo-controlled clinical trial. Phytother Res. February,2019;33(2):379-386

27. Hajhashemi M, Ghanbari Z, Movahedi M, Rafieian M, Keivani A, Haghollahi F. The effect of Achillea millefolium and Hypericum perforatum ointments on episiotomy wound healing in primiparous women. J Matern Fetal Neonatal Med. January,2018;31(1):63-69

28. Faraji A, Aghdaki M, Hessami K, et al. Episiotomy wound healing by Commiphora myrrha (Nees) Engl. and Boswellia carteri Birdw. in primiparous women: A randomized controlled trial. J Ethnopharmacol. September,2021;264:1-6

29. Moudi Z, Edozahi M, Emami SA, Asili J, Pour MS. Effects of mastic oleoresin on wound healing and episiotomy pain: A mixed methods study. J Ethnopharmacol. March,2018;214:225-231

30. Alhashim M, Lombardo J. Effect of Topical Garlic on Wound Healing and Scarring: A Clinical Trial. Dermatol Surg. May,2020;46(5):618-627 